\title{
OBSERVATIONS ON THE BREEDING BIOLOGY OF BRAHMINY KITE HALIASTUR INDUS IN CAUVERY DELTA REGION
}

\author{
S. Sivakumar ${ }^{1}$ and J. Alphonse Jayabalan ${ }^{2}$
}

${ }^{1}$ Bombay Natural History Society, Hornbill House, S.B. Singh Road, Mumbai, Maharashtra 400023, India

${ }^{2}$ Lecturer in Zoology, A.V.C. College, Mannampandal, Tamil Nadu, India

\section{ABSTRACT}

The incubation period of Brahminy Kite Haliastur indus was 26 to 28 and nestling period was from 43-45 days. Fresh water paddy field crabs Paratelphusa sp. and fresh water fishes made $30 \%$ in the prey items delivered to the nest. Three peak periods, 0800-0900h, 1000-1200h and 1500$1700 \mathrm{~h}$ were observed within a day for the delivery of prey. Decline of 0.58 prey item/hour(h)/nest during the first five weeks of nestling period to 0.45 prey item/h/nest during sixth and seventh weeks (Pearson's correlation coefficient $r^{2}=$ $0.448 ; y=0.201)$ was noticed.

\section{KEYwORDS}

Brahminy Kite, Breeding biology, Haliastur indus, inccubation period, prey delivery, nesting period

In India, since 1945 there have been very few good details published about the breeding biology of any Indian Raptor (Brown, 1976). Breeding biology of a few Indian forest raptors have been published in the last two decades (Naoroji, 1983, 1997; Prakash, 1996), which deal with some preliminary or detailed breeding biology. Still, detailed breeding study of several Indian raptors in lacking.

Breeding ecology of Brahminy Kite Haliastur indus was studied during 1996-97 (December-April). Brahminy Kite is a mediumsized hawk affecting tidal creeks, docks, dammed reservoirs, rivers, jheels, inundated rice-fields, ponds and flooded areas and distributed throughout India. Preliminary breeding information such as nest, clutch size, incubation period and participation of sexes in breeding activities are available (Ali \& Ripley, 1987).

\section{STUdy AREA}

The study was carried out in four different villages called Aduthurai, Thiyagarajapuram (in Thanjavur District), Sathanur and Thiruvaduthurai (in Thiruvarur District) in Tamil Nadu. The entire area falls in the Cauvery Delta region, which has the Coleroon River as northern boundary, Bay of Bengal as eastern, Muthupettai marshes as southern and Lower Anaicut as western boundaries. Agricultural fields are predominant in its landscape. Paddy and sugar cane are the main crops cultivated. In non-cultivated areas, vegetation changes from grass-toshrub-to tree dominated communities. Common shrub species include Prosopis spicigera, Jatropha glandulifera, Ipomea comea, Adhathoda vesica and Calotropis gigantica. Common tree species include Tamarindus indicus, Azadirachta indica, Ficus religiosa, Entrolobium saman, Cocos nucifera, Casuarina indica, Tectona grandis, Acacia arabica, Mangifera indica, Moringa olifera and Morinda tinctona.
Cauvery River, Veeracholoan Canal and their tributaries and fresh water ponds are important water sources of the area. The area is strongly influenced by northeast and southwest monsoons with a mean annual precipitation of $80.2 \mathrm{~cm}$, mean monthly temperatures range between 27 to $33^{\circ} \mathrm{C}$ (maximum) and between 17 to $25^{\circ} \mathrm{C}$.

\section{Materials And Methods}

Active nests of Brahminy Kites were located by searching known territories and observing soaring birds. The nests were observed during regular brief visits. Data on incubation, food and feeding of nestlings, were collected from eight nests. Focal animal sampling technique (Altmann, 1974) was applied to monitor parental behaviour and activities of the nestlings. The sex of parents was determined from size differences (Meenakshi, 1990) and from behaviour. The observation spots were always located within $100 \mathrm{~m}$ from the eyries with caution so as to not disturb the pairs. Various spans of time was spent at different nests. Total of 296 hours 52 minutes with minimum of $21 \mathrm{~h} 20$ min at a nest in Sathanur and maximum of $73 \mathrm{~h} 55 \mathrm{~min}$ at a nest in Aduthurai was spent during the study.

\section{Results}

Of the eight nests studied, three nests were situated within human habitation, three were at the periphery of waterbodies and two among agricultural land. Half of the nests were constructed on Cocos nucifera trees. The height of nest trees ranged from 13$15 \mathrm{~m}$. Most of the broods $(\mathrm{n}=6)$ had two nestlings each, while one brood had three nestlings and the other, one. The incubation period was 26 to 28 days and nestling period was from 43-45 days (Table 1).

Fresh water paddy field crabs Paratelphusa sp. and fresh water fishes comprised $30 \%$ in the prey items delivered to the nest. Frogs, garden lizards, birds and field rats were also delivered by Brahminy Kite. Sixty five percent of the food materials delivered to the nest remained unidentified (Fig. 1). Three peak periods were observed within a day for the delivery of prey: 0800-0900h, $1000-1200 \mathrm{~h}$ and $1500-1700 \mathrm{~h}$. Minimum frequencies of prey deliveries were recorded immediately after dawn and at dusk (Fig. 2).

The male Brahminy Kite brought most of the prey items to the nest for the first three weeks of nestling period, while the female spent her time brooding and feeding the young with the delivered prey items. An average of 0.58 prey items $/ \mathrm{h} /$ nest was delivered during the first five weeks of nestling period and a steep decline in the delivery rate $(0.45$ prey item/h/nest $)$ was noticed during the sixth and seventh weeks (Pearson's correlation coefficient $r^{2}$ $=0.448 ; \mathrm{y}=0.201)$. One of the nestlings of the three-chick brood 
Table 1. Details of Brahminy Kite broods studied during the study

\begin{tabular}{llllc}
\hline Location & Habitat & $\begin{array}{l}\text { Height of nest tree } \\
(\mathbf{m})\end{array}$ & $\begin{array}{l}\text { Incubation period } \\
\text { (days) }\end{array}$ & $\begin{array}{l}\text { No. of chicks } \\
\text { (days) }\end{array}$ \\
\hline Thiruvaduthurai & Human habitation & Cocos nucifera (15) & 27 & 2 \\
Thiruvaduthurai & River bank & Borassus flabellifer (13) & 27 & 2 \\
Sathanur & River bank & Mangifera indica (15) & 27 & 2 \\
Sathanur & Human habitation & Cocos nucifera (15) & 28 & 4 \\
Thiyagarapuram & Agricultural land & Tamarindus indica (13) & 26 & 2 \\
Aduthurai & Near pond & Cocos nucifera (14) & 27 & 2 \\
Aduthurai & Close to Mutton Market & Cocos nucifera (14) & 27 & 4 \\
Aduthurai & Agricultual land & Terocarpus marsupium (13) & 27 & 45 \\
\hline
\end{tabular}

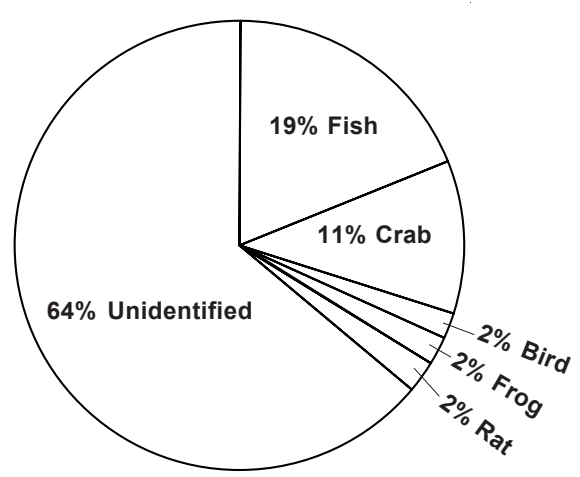

Figure 1. Prey composition in the diet of Brahminy Kite observed during the study

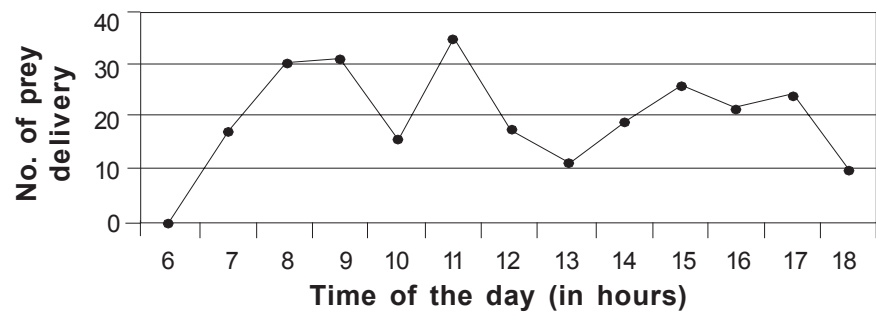

Figure 2. Diurnal pattern of prey delivery in Brahminy Kite observed during the study

died on the $43^{\text {rd }}$ day of its growth.

\section{Discussion}

Generally, the parental care exhibited by Brahminy Kite during chick rearing is characteristic of large raptors (Brown \& Amadon, 1968; Newton, 1979). Although not often found at the nest, male Brahminy Kites play a critical role in the breeding success by providing most of the food for the female and the nestlings early in the chick rearing period. Females are closely associated with the nest early during chick rearing, but as the young grow and develop thermoregulatory capabilities, they gradually brood and shade less often. By the fifth week, Brahminy Kite nestlings attempt to feed themselves. In subsequent weeks, as the nestlings become more proficient at feeding, females spend less time on the nest and return principally to deliver prey and occasionally to feed the young.

Decline in prey rate in later part of nestling period was noticed among Brahminy Kites. This appears to be typical of Golden Eagles (Gordon, 1927; Brown, 1955; Brown \& Amadon, 1968). In fact, Brown (1955) suggested that parents intentionally reduced the food supply to offspring late during chick rearing and the reduction facilitated fledging process.

There was no significance in the amount of food provided to different size of broods. Male delivered a fairly uniform supply of prey, which supplemented the requirements of the young which were greatest. This pattern of food delivery may reflect a limited capacity in the male for prey capture and the need for the female to fetch suggested that the total amount of food capture by adult raptors may be determined primarily by foraging success and not the food requirements of the young (Timbergen, 1940; Snyder \& Snyder, 1973; Newton, 1978).

On two occasions, it was observed that Brahminy Kites brought larger prey items (garden lizard \& rat) to the nest, cached them, and retrieved to feed their nestlings at intervals. Caching and retrieval during peak number of prey delivery in early nestling stage has also been reported in several raptor species (eg. Ratcliff, 1980).

\section{REFERENCES}

Ali, S. and S.D. Ripley (1987). Compact Handbook of the Birds of India and Pakistan. Oxford University Press, New Delhi.

Altmann, J. (1974). Observational study of behaviour sampling methods. Behaviour 49: 227-267.

Brown, L.H. (1955). Supplementary notes on the biology of the large birds of prey of Enbu District, Kenya Colony. Ibis 97: 38-64.

Brown, L.H. and D. Amadon (1968). Hawks, Eagles and Falcons of the World Vol. 1\&2, New York, McGraw Hill.

Gordon, S. (1927). Days with the Golden Eagle. Williams \& Norgate, London.

Meenakshi, S. (1990). Studies on reversed sexual size dimorphism in Brahminy Kite Haliastur indus nestlings. M.Sc. Thesis. Bharathidasan University, Thiruchirappalli.

Naoroji, R. (1983). Observations on the Crested Serpent Eagle (Spilomis cheel) in Rajpipla Forest, south Gujarat. Journal of the Bombay Natural History Society 80(2): 273-285.

Naoroji, R. (1997). First breeding record of the Collared Falconet Microhierax caenulescens for the Indian subcontinent in Corbett National Park, Uttar Pradesh. Journal of the Bombay Natural History Society 94: 267-272.

Newton, I. (1978). Feeding and Development of Sparrowhawk Accipiter nisus nestlings. Journal of Zoology 184: 465-487.

Newton, I. (1979). Population Ecology of Raptors. Vermillion, Butco Books, South Dakota.

Prakash, V. (1996). Status distribution and breeding biology of Lesser Spotted Eagle Aquila pomanna hastate in Keoladeo National Park, 
pp.357-375. In: Meyburg, B.U. and R.D. Chancellor (Editors). Eagle Studies. World Working Group on Birds of Prey (WWGBP), London. Ratcliff, D.A. (1980). The Peregrine Falcon. Poyser, Berkhaomsted, UK. Snyder, N.F.R. and H.A. Snyder (1973). Experimental study of feeding rates of nesting Cooper's Hawks. Condor 75: 461-487.

*Timbergen, L. (1940). Beobachtugen ueber die arbeitsteilung des turmfalken (Falco tinunculus) wachrend der forpflanzungs zeil. Ardea 29: 63-98.

* Original not referred.

\section{ACKNOWLedGement}

We express our deep sense of gratitude to Prof. A. Rajmohan, M.Sc., M phil., Principal and Dr. R. Kanakasabai, HOD, Department of Zoology, A.V.C. College, Mannampandal for providing the necessary facilities and we thank Mr. A. Hajamohaideen, S. Senthilkumar and G. Murugesan for their help in the field.

\section{ADDITIONS TO THE BIRDS OF JODHPUR CITY, RAJASTHAN}

\section{Sumit Dookia and V.K.Paudey}

Desert Regional Station, Zoological Survey of India, Jhalamand, Pali Road, Jodhpur, Rajasthan 342005, India

Email: sdookia_gazelle@rediffmail.com

Jodhpur City $\left(26^{0} 19^{\prime} \mathrm{N} \& 73^{\circ} 8^{\prime} \mathrm{E}\right)$ is situated on the eastern fringe of the Thar Desert, Rajasthan. The City has waterbodies most of which are perennial such as Kailana Lake, Takhat Sagar, Nagadari Pond, Guda Bada Talab and Kuri Haud Pond that are good sites for bird watching. A preliminary list of 20 species of water birds was published by Agoramoorthy and Mohnot (1986). Chhangani (2002) published a comprehensive checklist of the birds of Jodhpur with 158 species of birds. The following eight species are recorded for the first time from Jodhpur City, increasing the total to 166 species.

Grey-headed Cannery Flycatcher Culicicapa ceylonensis (Swainson, 1820) Resident, uncommon, seen inside plantation on Kuri Haud near City. A flock of eight birds were flying at canopy level of Acacia tortolis, Prosopis juliflora and Azadirachta indica trees. All were actively hunting for flying insects.

Yellow-legged Green Pigeon Treron phoenicoptera (Latham, 1790) Common since five or six years in the city. More than 100 birds can be easily located on Ficus religiosa trees at the City Railway Station area.

Comb Duck Sarkidiornis melanotos (Pennant, 1769)

Reported from Kuri Haud area last winter. A male was found dead due to high voltage electric wire with an injury in its under parts (Kumar et al., 2002).

Red-Crested Pochard Rhodonessa rufina (Pallas, 1773)

Winter visitor, sighted in Kailana Lake, in a flock of seven birds. The flock was sighted thrice in the morning hours basking on the bank.

Tawny Eagle Aquila rapax (Temminck, 1828)

Resident, two birds were reported from Machia Safari Park during December 2002, and nine birds were sighted in 2001 from Guda Bishnoian village ponds.

Himalayan Griffon Gyps himalayensis (Hume, 1869)

Common since last two to three years with mixed flock of Eurasian Griffon Vultures. They can be easily sighted on dumping grounds of Municipal Corporation of Jodhpur City and nearby hillocks of Barli, Arna and Kailana Lake. A maximum of about 200 were noticed in January 2003.

Purple Heron Ardea purpurea (Linnaeus, 1766)

Resident, but winter visitor in this region. One bird was sighted in marshy area of Takhat Sagar Lake in October 2002 and two were observed feeding in the swampy marsh of Guda Bishnoian Pond during December 2001.

Dalmation Pelican Pelecanus crispus (Bruch, 1832)

A flock of three birds were sighted in Guda Bada Talab in December 2002.

\section{REFERENCES}

Chhangani, A.K. (2002). Avifauna in around Jodhpur City, Rajasthan, India. Newsletter for Birdwatchers 42(2): 24-26.

Agoramoorthy, G. and S.M. Mohnot (1986). Migratory water birds around Jodhpur (India). Tigerpaper 13(1): 4-7.

Kumar, S., C. Sivaperuman, M. Pardeshi and Q.H. Baqri (2002). Comb duck Sarkidionis melanotus (Pennant, 1769) in the Thar Desert of Rajasthan, India. Newsletter for Birdwatchers 42(5): 102. 